\title{
RESTRUKTURISASI PSIKOTERAPI DAN RELAKSASI EMOSI, OTOT UNTUK MENGURANGI INSOMNIA
}

\author{
Aries Dirgayunita ${ }^{1}$, Benny Prasetiya ${ }^{2}$ \\ STAI Muhammadiyah Prodi Pendidikan Agama Islam
}

\begin{abstract}
Backgound: Difficulty sleeping or insomnia is a complaint about the lack of quality sleep caused by one of; it is difficult to enter sleep, often wake up at night then difficulty to go back to sleep, wake up too early, and sleep badly. Insomnia is not caused by at least one person sleeping, because everyone has a number of hours of sleep on their own. This is a case study of subjects who experience symptoms of insomnia due to stress. Besides subject matter experience, because of academic and family factors. Interventions used are cognitive restructuring and emotional relaxation therapy, muscle. Methods: This study uses a psychological assessment which is an activity to collect subject data using data collection techniques from observation, interviews, and psychological tests. Result: the results of therapy that have been carried out using the interview method conducted directly to the subject, several days after the therapy was carried out experienced significant success. Conclusion: the application of restructuring of psychotherapy and relaxation of emotions, muscles can reduce insomnia
\end{abstract}

Keywords: Psychotherapy, Emotional Relaxation, Insomnia

\section{PENDAHULUAN}

Stres dan kecemasan seringkali terjadi pada kehidupan seseorang yang disebabkan oleh semua peristiwa seharihari. Salah satu terapi spesialis keperawatan jiwa sebagai penatalaksanaan cemas adalah dengan progressive muscle relaxation (relaksasi otot progresif) yang merupakan bagian dari terapi relaksasi. Teknik relaksasi otot progresif yaitu teknik yang dilakukan dengan cara peregangan otot kemudian dilakukan relaksasi otot. Beberapa manfaat teknik ini di antaranya untuk menurunkan ketegangan otot, kecemasan, nyeri leher dan punggung, membangun emosi positif dari emosi negative.

$$
\text { Beberapa teori psikologi }
$$

menjelaskan terjadinya gangguan kecemasan social yang diikuti dengan pola terapinya. Masing-masing perspektif teoritis berbeda satu sama lain dalam teknik-teknik dan tujuannya, akan tetapi ada satu hal yang sama, yakni mendorong klien untuk menghadapi sumber-sumber kecemasannya bukan menghindar (Asrori, 2015)

Tidur merupakan kebutuhan bukan suatu keadaan istirahat yang tidak bermanfaat, tidur merupakan proses yang diperlukan oleh manusia untuk pembentukan sel-sel tubuh yang rusak (natural healing mechanism). Disamping itu tidur bagi manusia dapat mengendalikan irama kehidupan seharihari. Salah satu fungsi tidur yang paling utama adalah untuk memungkinkan system syaraf pulih setelah digunakan selama satu hari. Kekurangan tidur dapat menyebabkan gangguan mood, emosi, 
konsentrasi dan menimbulkan malas. Latihan relaksasi dapat digunakan untuk mengurangi gejala insomnia, terapi ini merupakan bentuk terapi psikologis yang mendasarkan pada teori-teori behavioris (Esty Aryani Safithry, 2014).

Setiap tahun diperkirakan sekitar $20 \%$ - 50\% orang dewasa melaporkan adanya gangguan tidur dan sekitar $17 \%$ mengalami gangguan tidur yang serius. Insomnia adalah yang paling sering dilaporkan dari semua masalah tidur (Bixler, Kales, Soldatos, Kales, Healey 1979). Penderita insomnia mengalami kesulitan kronis untuk tidur, sering terbangun dari tidur dan atau tidur singkat, berbeda dengan orang yang memang waktu tidurnya pendek (short sleepers). Pada short sleepers meski waktu tidur singkat/pendek, tetap merasa bugar sewaktu bangun tidur, berfungsi secara normal di siang hari dan tidak mengeluh tentang tidur di malam hari.

Kesulitan tidur atau insomnia adalah keluhan tentang kurangnya kualitas tidur yang disebabkan oleh satu dari; sulit memasuki tidur, sering terbangun malam kemudian kesulitan untuk kembali tidur, bangun terlalu pagi, dan tidur yang tidak nyenyak. Insomnia tidak disebabkan oleh sedikitnya seseorang tidur, karena setiap orang memiliki jumlah jam tidur sendirisendiri. Tapi yang menjadi penekanan adalah akibat yang ditimbulkan oleh kurangnya tidur pada malam hari seperti kelelahan, kurang gairah, dan kesulitan berkonsentrasi ketika beraktivitas (Esty Aryani Safithry, 2014).

Insomnia berkontribusi dalam penurunan kualitas hidup lansia, mengurangi sistem kekebalan tubuh, gangguan kognitif, status fungsional, peningkatan risiko jatuh dan peningkatan angka kematian yang lebih tinggi. Jika masalah tidur tidak terpenuhi secara adekuat akan berdampak pada lansia berupa kelelahan, perubahan mood, mudah marah, mengantuk disiang hari, cemas akan tidur, kurangnya konsentrasi, perburukan memori, kualitas kinerja atau aktivitas yang buruk, kurangnya motivasi dan energi, dan peningkatan tekanan darah (Hardani, Susanti, \& Putri, 2016). Insomnia bukan suatu penyakit, tetapi merupakan suatu gejala yang memiliki berbagai penyebab yang dapat ditandai dengan adanya gangguan fisik ataupun psikologis, seperti kelainan emosional (kecemasan, kegelisahan, depresi atau ketakutan), fisik, factor lingkungan gaya hidup, rokok, kopi, jam kerja yang tidak teratur dan pemakaian obat-obatan. Terkadang seseorang tidur dalam keadaan gelisah dan belum puas tidur. Sehingga sering terbangun beberapa jam kemudian dan sulit untuk tidur kembali.

Setiap orang pada dasarnya pernah mengalami insomnia, sebuah survey yang dilakukan oleh National Institut of Health di Amerika menyebutkan bahwa pada tahun 1970 menunjukkan bahwa total penduduk yang mengalami insomnia $17 \%$ dari populasi, presentase penderita insomnia lebih tinggi dialami oleh orang yang lebih tua, dimana 1 dari 4 pada usia 60 tahun mengalami sulit tidur yang serius (Purwanto, 2008)

Penyembuhan terhadap insomnia tergantung dari penyebab yang menimbulkan insomnia. Bila penyebabnya adalah kebiasaan yang salah atau lingkungan yang kurang kondusif untuk tidur maka terapi yang dilakukan adalah merubah kebiasaan dan lingkungannya. Sedangkan untuk penyebab psikologis maka konseling dan terapi relaksasi dapat digunakan untuk mengurangi gangguan 
sulit tidur, terapi ini merupakan bentuk terapi psikologis yang mendasarkan pada teori-teoribehavioris (Esty Aryani Safithry, 2014).

Intervensi yang digunakan untuk insomnia dapat dengan pendekatan kognitif dan terapi relaksasi emosi, otot yang merupakan salah satu teknik di dalam terapi perilaku. Selain itu farmakologi juga merupakan salah satu cara untuk pengelolaan jangka pendek gangguan insomnia (Blais, Gendrom, Mimeault, Morin. 1997).

Relakasasi merupakan pengaktifan dari saraf parasimpatetis yang menstimulasi turunnya semua fungsi yang dinaikkan oleh sistem saraf simpatetis, dan menstimulasi naiknya semua fungsi yang diturunkan oleh saraf simpatetis. Masing-masing saraf parasimpatetis dan simpatetis saling berpegaruh maka dengan bertambahnya salah satu aktivitas sistem yang satu akan menghambat atau menekan fungsi yang lain (Esty Aryani Safithry, 2014)

Salah satu bentuk dari terapi perilaku terhadap penurunan insomnia adalah dengan teknik relaksasi. Teknik relaksasi pertama kali dikenalkan oleh Edmund Jacobson (1938), seorang Psikolog dari Chicago yang mengembangkan metode fisiologis melawan ketegangan dan kecemasan. Relaksasi otot progresif sampai saat ini menjadi metode relaksasi termurah, tidak memerlukan imajinasi, tidak ada efek samping, mudah dilakukan, membuat tubuh dan pikiran tenang, rileks serta lebih mudah untuk tidur (Soewondo, 2012).

\section{METODE PENELITIAN Metode Asesment}

Asesment psikologi merupakan kegiatan yang dilakukan guna mengumpulkan data subjek dengan menggunakan metode yaitu :

\section{Observasi}

Dilakukan pada saat wawancara dan juga pada saat tes psikologi berlangsung. Tujuan dari penggunaan metode ini untuk melihat pola perilaku dan juga ekspresi wajah subjek dalam segala situasi (saat wawancara ataupun tes psikologi).

\section{Wawancara}

Tujuan dari penggunaan metode ini untuk mengumpulkan data-data yang terkait dengan subjek guna menunjang dalam melakukan penegakan diagnose dari permasalahan subjek. Wawancara dilakukan dengan subjek (autoanamnesa) dan teman kost (alloanamnesa).

\section{Tes Psikologi}

Tujuan dari penggunaan metode ini untuk memperkuat hasil wawancara dan juga mengetahui pola kepribadian subjek. Serta untuk mengetahui konflik-konflik yang terjadi pada diri subjek yang berhubungan dengan munculnya keluhan yang subjek alami. Tes yang diberikan adalah grafis (pola kepribadian) dan tes TAT (mengetahui konflik-konflik).

Dasar-dasar untuk menilai tingkat efektivitas terapi tersebut digunakan dalam penelitian ini dengan menanyakannya kepada subjek selama proses terapi, saat evaluasi akhir dan masa follow-up. Evaluasi dilakukan dengan menggunakan self report, wawancara, dan kuisioner pasca terapi. Kepada kedua subjek ditanyakan mengenai hal-hal yang subjek rasakan bermanfaat, sesi terapi atau teknik terapi yang paling membantunya atau paling menyulitkannya, atau hal-hal lain yang klien rasakan selama proses 
terapi, bahkan perubahan negatif jika mungkin ada. Kedua subjek mengaku jika mereka mengalami banyak perubahan, menurunnya tingkat kecemasannya, juga merasa sangat terbantu dengan teknikteknik terapi yang telah diajarkan

\section{HASIL PENELITIAN}

Subjek merupakan anak kedua dari tiga bersaudara kandung dalam keluarganya. Kedua orang tua subjek protektif terhadap subjek terutama mengenai pendidikan subjek. Orang tua subjek ingin anak-anaknya mendapatkan pendidikan yang baik dan tidak ingin anaknya mempunyai prestasi akademik yang rendah. Meskipun, subjek merasa bahwa dirinya bukanlah anak yang pintar, pandai dan selalu memperoleh prestasi yang baik dalam bidang akademik. Akan tetapi, orang tua subjek terutama ayah subjek sering kali membandingbandingkan subjek dengan adiknya yang selalu memperoleh peringkat satu (1) dalam bidang akademik di sekolahnya dan saudara sepupunya yang seusia dengan subjek juga memperoleh hal yang sama. Selain itu, ayah subjek juga meminta untuk bias memperoleh prestasi yang lebih baik. Hal tersebut terus berlanjut hingga subjek kuliah.

Dalam hal pendidikan orang tua subjek terutama ayah subjek sangat keras. Seperti, sewaktu SMA orang tua subjek memberikan hukuman kepada subjek kerena subjek memperoleh hasil belajar yang dibawah rata-rata (raport jelek). Subjek mengatakan bahwa dirinya tidak diberi uang saku selama satu bulan dan dirinya tidak diajak berkomunikasi oleh orang tuanya selama satu (1) minggu. Subjek merasa dirinya seperti anak tiri (bukan anak kandung), biasanya subjek makan bersama kedua orang tuanya.
Namun pada saat itu, subjek dalam satu (1) minggu tidak diajak berkomunikasi saat makan bersama. Selain itu, subjek selama satu (1) minggu tidak ditegur/disapa, hanya didiamkan saja. Semenjak kejadian itu, subjek berusaha dan belajar agar memperoleh hasil yang lebih baik lagi.

Jurusan yang diambil oleh subjek saat ini merupakan saran dari kakak perempuan subjek. Yang menurut subjek, jurusan yang diambilnya ini kelak memberikan kemudahan kepada subjek untuk mendapatkan pekerjaan. Selain itu, menurut subjek jurusan yang subjek ambil sekarang ini tidak melibatkan hitungan (bidang matematika) karena subjek merasa dirinya tidak pintar dan pandai seperti adik laki-lakinya maupun kakak perempuan dan sepupunya yang selalu dijadikan pembanding oleh kedua orang tuanya terutama ayah subjek. Oleh karena itu, subjek merasa tidak pecaya diri dengan kemampuan yang dimilikinya. Sehingga subjek tidak berani bercerita kepada keluarganya ketika dirinya sedang menghadapi masalah atau mengalami kesulitan terutama dalam bidang akademik. Meskipun subjek sudah mencoba untuk menceritakan permasalahan yang dihadapinya seperti subjek tahu bahwa dirinya kurang mampu dalam bidang akademik atau saat mengulang kembali dari awal dalam membuat skripsi. Hal tersebut subjek ceritakan kepada keluarganya baik kedua orang tua maupun kakak perempuannya dan pacar. Akan tetapi, subjek merasa mereka tidak memberikan jawaban/respon yang positif dan tidak memberikan dukungan yang bisa membuat subjek lebih bersemangat dan tidak membuat takut, cemas dalam mengerjakan skripsi maupun saat proses ujian skripsi. Respon yang 
diberikan keluarganya membuat subjek menjadi lebih tidak percaya diri, takut dan cemas. Sehingga hal tersebut menjadikan konflik dalam diri subjek. Selain itu, hal tersebut juga menjadi pikiran yang mengganggu subjek pada saat menjelang tidur serta memunculkan perasaan cemas, takut dan marah. Akan tetapi, hal itu tidak bisa subjek ungkapkan dan nyatakan dalam perilaku. Sehingga memunculkan pikiran-pikiran negative yang berlebihan, seperti takut tidak lulus tahun ini dan harus mengulang dari awal.

Setelah lulus kuliah sarjana ini, subjek mempunyai keinginan untuk bekerja. Namun oleh ayahnya, subjek diminta untuk melanjutkan kuliah saat hal itu, di utarakan oleh subjek kepada ibunya. Subjek mendapatkan respon yang kurang positif dari ibunya. Sehingga hal itu, membuat subjek menjadi tidak percaya diri dan merasa tidak mampu dengan kemampuan yang dimilikinya. Menurut subjek, ibunya menyatakan bahwa dirinya tidak akan mampu untuk melanjutkan ke pendidikan yang lebih lanjut (mengambil kuliah S2) karena menurut ibu subjek, sulit dan selama ini subjek dianggap kurang mampu serta sering kali disbanding-bandingkan oleh ibu subjek. Pada akhirnya, menurut subjek kedua orang tuanya meminta subjek untuk bekerja dan melanjutkan kuliah. Hal itu, tidak bisa subjek tentang dan harus dilaksanakan karena menurut subjek jika ayahnya sudah meminta dan mengatakan sesuatu anak-anaknya menerima dan melaksanakannya meskipun hal tersebut tidak sesuai dengan keinginan anak-anaknya.

Berdasarkan assessment dapat diketahui bahwa subjek dituntut dan sering kali kemampuan subjek dibandingbandingkan oleh keluarga terutama ayah, ketika subjek tidak mampu mengatasi masalah ataupun tidak memperoleh hasil ataupun prestasi yang baik yang di harapkan oleh kedua orang tuanya. Menurut Adler (dalam Alwisol, 2004: 100-101), pola asuh orang tua yang memberikan perlakukan salah pada anak dan ditekan dalam mengembangkan minatnya dapat menyebabkan anak menjadi ketergantungan dan mengembangkan perasaan inferioritas yang berlebihan pada anak. Selain itu, hal tersebut dapat menjadi sumber utama penyebab dari neurotik. Sehingga bias memunculkan anak yang memiliki kepribadian cenderung ragu-ragu, tidak percaya diri, sensitif, mudah putus asa dan kecemasan. Selain itu, pola asuh orang tua yang memberikan hadiah atau hukuman bagi tingkah laku anak bila anak melakukan sesuatu hal sesuai dengan keinginan/harapan orang tua ataupun sebaliknya.

Hal tersebut juga terlihat dari hasil tes (tes grafis) yang menunjukkan bahwa pola kepribadian subjek yaitu cemas, dependent (ketergantungan), kurang percaya diri, tertutup dan menerima tekanan ataupun larangan yang tidak disetujui. Hal tersebut juga terlihat dari hasil tes (tes TAT) yang menunjukkan bahwa selama ini, subjek memiliki kebutuhan afiliasi dan afeksi dari keluarga maupun orang lain yang berupa perhatian, kasih sayang dan dukungan. Selain itu, subjek juga memiliki kebutuhan untuk mencari pertolongan serta menggantungkan diri pada keluarga ataupun orang lain. Akan tetapi, kebutuhan-kebutuhan tersebut direpresnya dan dirasionalisasikan. Karena subjek cenderung bersikap pasif terhadap kondisi-kondisi yang tidak tertanggungkan dan menerima tekanan yang tidak 
disetujuinya dengan terpaksa untuk menghindar dari hambatan ataupun hukuman. Selain itu, subjek memiliki kesalahan dalam memahami stimulus yaitu subjek gagal memilah tanda-tanda yang ada pada stimulus, sehingga stimulus yang benar dihubungkan dengan hukuman dan yang salah dihubungkan dengan renforcement (Alwisol, 2004: 416). Subjek megeneralisasi stimulus baru yang muncul dengan stimulus yang sebelumnya sehingga subjek membuat respon yang sama terhadap situasi yang berbeda dan memunculkan tingkah laku yang kacau.

Dalam menghadapi dan menyelesaikan permasalahannya, subjek cenderung menerima dan mendiamkannya. Menurut Freud (Davidson, 1994: 38), rasa tidak nyaman yang dialami ego yang cemas dapat dikurangi melalui mekanisme pertahanan diri. Mekanisme pertahanan diri yang dilakukan subjek adalah represi, dimana hal tersebut subjek lakukan untuk mengurangi kecemasan yang muncul saat menghadapi konflik. Kecemasan tersebut subjek repres dan terbawa ke alam bawah sadar sehingga berpotensi muncul kembali ke alam sadar dan memunculkan kecemasan.

Dari hasil kuesioner riwayat gangguan tidur yang diperoleh dari subjek, dapat diketahui bahwa subjek mengalami sulit tidur yang dapat dikategorikan dalam gangguan insomnia primer. Hasil assessment (autoanamnesa dan alloanamnesa) juga mempertegas bahwa subjek hampir setiap hari mengalami kesulitan dalam mempertahankan tidurnya terutama tidur pada malam hari. Sehingga hal ini membuat aktivitas subjek pada siang hari menjadi terganggu. Karena subjek mengalami kelelahan, capek, ngantuk, perut kembung dan mual. Selain itu, subjek menjadi tidak konsentrasi, seringkali lupa dan tidak fokus karena kuantitas dan kualitastidur yang kurang pada malam hari.

Menurut Nevid (2005), gangguan tidur (sleep disorder) dikarenakan oleh dua factor yaitu, biologis; masalah fisik, kerusakan genetis serta penggunaan obatobatan yang mempengaruhi tidur normal. Faktor yang kedua yaitu psikologis yang berupa kecemasan yang memuncak, depresi, stress, seringnya terjadi perubahan dalam waktu tidur bangun dan pemaparan terhadap trauma. Subjek mengalami gangguan tidur dikarenakan oleh faktor kedua yaitu psikologis. Dimana subjek mengalami kecemasan atas konflik-konflik yang dialaminya saat ini maupun di masa lalu.

Subjek menggunakan berbagai cara untuk mencoba mengatasi kesulitan tidurnya, dengan mengkonsumsi obat tidur yang diresepkan oleh dokter maupun obat tidur yang di jual bebas (obat tidur merk lelap), maupun olah raga. Selain itu, subjek mencoba tidak tidur sendiri (ditemani) dan tidak tidur pada siang hari agar pada malam hari subjek bisa tidur lelap. Akan tetapi, hal itu belum bisa mengatasi keluhan yang dihadapi oleh subjek yaitu kesulitan dalam mempertahankan tidur pada malam hari.

Diagnosis dan Prognosis

\section{Diagnosis}

Axis I : 307.42 Gangguan Tidur (Insomnia Primer)

Axis II $\quad$ : Ciri kepribadian; Cemas, dependent, kurang percaya diri dan tertutup

Axis III :-

Axis IV : Sterssor berasal dari masalah pendidikan 
(skiripsi yang belum selasai) dan keluarga (ayah akan memberikan hukuman yaitu tidak memberi biaya hidup jika subjek tidak bisa lulus)

Axis V : GAF : 70-61

Gejala ringan dan menetap, disabilitas (dalam aktivitas seharihari) ringan dalam fungsi secara umum masih baik.

\section{Prognosis}

Prognosa untuk kepilihan subyek adalah baik, mengingat ada beberapa hal yang positif yang Nampak dimiliki oleh subyek diantaranya; bahwa subjek memiliki motivasi dan dukungan yang baik dari teman-temannya maupun keluarganya untuk membantu subjek sembuh dari permasalahan yang dialaminya yaitu sulit tidur (mempertahankan tidur pada malam hari). Subyek mempunyai keinginan baik untuk menyelesaikan permasalahan yang dihadapinya. Misalnya yang berkaitan dengan skripsinya, subyek berusaha untuk meyakinkan dirinya bahwa bisa lulus tahun ini.

\section{Intervensi}

Intervensi yang berfokus pada membantu subyek untuk memahami msalah yang dihadapi (restrukturisasi kognitif) dan relaksasi emosi, otot untuk mengendalikan perasaan cemas, tegang yang dirasakan subyek.

Sesi 1

Pada tahap 1 ini adalah tahap awal dalam pelaksanaan terapi, dimana pada tahap pertama terapis melakukan konseling kepada subjek, hal ini dilakukan dengan tujuan untuk membantu subjek memahami masalah, konflikkonflik dan kecemasan yang dialaminya yang mengakibatkan kesulitan tidur yang dirasakannya serta membantu mengungkapkan hal-hal yang direpres oleh subjek. Sehingga subjek dapat melakukan coping (penyesuaian) yang baik saat terjadi masalah yang berat dalam hidupnya serta menemukan solusi dan mengatasi permasalahan yang di hadapinya.

Pada tahap awal terapis meminta subjek untuk bercerita tentang masalahnya, perasaan atau pikiranpikirannya ketika menjelang tidur. Subjek menceritakan bahwa dirinya takut tidak bisa lulus tahun ini (Agustus 2009), takut mengulang skripsi dari awal lagi. Karena ayah subjek memberikan batasan waktu kepada subjek, jika subjek tidak lulus bulan Agustus tahun ini (2009) ayah subjek tidak akan membiaya subjek. Hal ini, mengganggu pikiran dan perasaannya pada saat akan tidur di malam hari. Subjek takut peristiwa yang pernah dialaminya pada saat SMA terulang kembali. Selain itu, subjek juga takut mengulang mengerjakan skripsi dari awal seperti yang pernah subjek alami sebelumnya. Subjek merasa bahwa peristiwa yang dialaminya sangat membekas di hatinya.

\section{Sesi 2}

Pada tahap ini, terapis dapat membuat sebuah kesimpulan bahwa subjek masih menyimpan konflikkonfliknya dalam alam bawah sadarnya. Berdasarkan hal ini, terapis meminta kesediaan subjek untuk mengungkapkan segala perasaan dan pikirannya tanpa ada hal yang di tutupi. Terapis menjelaskan pada subjek, ini dilakukan dengan tujuan untuk membantu subjek mengurangi beban atas konflik-konflik ataupun emosi- 
emosi negative yang selama ini subjek pendam.

Kemudian terapis meminta subjek untuk berbaring, dan dalam keadaan rileks. Selanjutnya terapis meminta subjek untuk mengatur nafas (menarik dan melepaskan nafas). Setelah itu, terapis meminta subjek untuk membayangkan dan menghadirkan segala perasaan/emosi dan pikiran serta pengalaman yang membuatnya merasakan emosi negative melalui setiap hembusan nafas yang subjek keluarkan, begitu seterusnya hingga 3 kali percobaan. Terakhir, terapis meminta subjek untuk membuka mata secara perlahan-lahan.

Setelah relaksasi release emosi/letting go selesai, terapis menanyakan mengenai perasaan subjek setelah melakukan relaksasi ini. "Saya seperti dikejar-kejar, capek sekali sampai nafas saya terasa berat dan saya harus cepat-cepat mengambil nafas kembali. Sepertinya yang mengejar itu adalah masalah-masalah yang sedang saya hadapi. Saya sadar bahwa hal itu harus saya hadapi dan selesaikan meski terasa berat bagi saya. Sebelumnya saya tidak pernah melakukan hal seperti ini karena selama ini pikiran, perasaan dan emosiemosi negatif yang saya rasakan hanya saya pendam sendiri dan tidak saya ungkapkan. Mungkin selanjutnya saya butuh melakukan hal ini beberapa kali untuk mengungkapkan emosi negative yang selama ini saya rasakan".

Sesi 3

Pada bagian akhir tahap ini, terapis memberikan feed back kepada subjek mengenai apa yang telah dilakukan. Selain itu, terapis meminta subjek untuk tetap melakukan latihan relaksasi untuk melepaskan emosi-emosi negatif subjek atas konflik yang selama ini direpresnya dalam ketidaksadarannya.

\section{PEMBAHASAN}

Kurang tidur dapat membahayakan bagi diri kita dan orang lain. Seseorang yang kurang tidur lalu mengemudi mobil sendiri sering mengalami kecelakaan fatal. Kurang tidur, dapat pula mengakibatkan masalah dalam keluarga dan perkawinan, karena kurang tidur dapat membuat orang cepat marah dan lebih sulit diajak bergaul. Bila tidur kurang lelap, maka kita akan merasa letih, lemah, dan lesu pada saat bangun. Kehilangan jam tidur meskipun sedikit mempunyai akibat yang sangat bagi semangat, kemampuan konsentrasi, kinerja, produktivitas, ketrampilan komunikasi, dan kesehatan secara umum, termasuk sistem gastrointestinal, fungsi kardiofaskuler dan sistem kekebalan tubuh (Purwanto, 2008).

Gangguan tidur yang sering muncul dapat digolongkan menjadi 4 yaitu : (1) insomnia; gangguan masuk tidur dan mempertahankan tidur, (2) hypersomnia; gangguan mengantuk atau tidur berlebihan, (3) disfungsi kondisi tidur seperti somnabolisme, night teror, dan (4) gangguan irama tidur (Purwanto, 2008).

Hasil intervensi yang dilakukan terhadap subyek, maka dapat diketahui bahwa terapi dengan menggunakan teknik relaksasi emosi, dan otot (progresif) serta restrukturisasi kognitif dapat membantu individu yang mengalami gangguan tidur (sleep disorder). Menurut Nevid (2005), gangguan tidur (sleep disorder) bisa disebabkan oleh dua faktor yaitu, masalah fisikseperti, penggunaan obat-obatan, kerusakan genetis. Faktor yang kedua yaitu psikologis yang berupa kecemasan, depresi, stres maupun perubahan dalam waktu tidur bangun dan pemaparan 
terhadap trauma. Teknik yang digunakan tersebut bertujuan untuk membantu subyek memahami masalah yang dihadapinya, konflik serta kecemasan yang dialaminya sehingga mengakibatkan subyek mengalami kesulitan tidur. Dengan menggali perasaan-perasaan marah, cemas dan takut (emosi-emosi negatif) yang direpres oleh subyek. Dapat membantu subyek melepaskannya secara perlahan-lahan sehingga subyek tidak mempunyai pemikiran yang negatif.

Intervensi yang digunakan pada kasus ini yaitu teknik relaksasi realise emosi, dan otot (progresif) serta restrukturisasi kognitif yang bertujuan untuk menghilangkan pemikiran negatif/irasional mengenai permasalahan yang dialami subyek. Dengan latihan relaksasi dapat memunculkan perasaan tenang dan rileks dimana gelombang otang semakin melambat akhirnya dapat membuat seseorang beristirahat dan tidur (Nida, 1997). Sedangkan restrukturisasi kognitif bertujuan untuk menghilangkan pemikiran negatif serta belajar untuk memperkuat hubungan antara tempat tidur dan tidur serta membatasi aktifitas ditempat tidur hanya untuk tidur.

\section{KESIMPULAN DAN SARAN}

Insomnia adalah masalah gangguan tidur berupa kesulitan untuk tidur yang disebabkan oleh kecemasan dan stres yang dialami oleh seseorang. Berdasarkan dari hasil asessment dan intervensi, dapat disimpulkan bahwa hasil dari terapi yang telah dilakukan dengan menggunakan metode wawancara yang dilakukan secara langsung kepada subjek, beberapa hari pasca terapi dilaksanakan. Subjek mengungkapkan bahwa dirinya mulai bisa mengatur ketegangan serta mengendalikan emosi-emosi negatif untuk mengurangi kecemasan dan kebingungan yang dialaminya selama ini. Selain itu, dengan didukung motivasi yang baik untuk mengatasi permasalahan yang dialaminya. Subjek menyadari bahwa dirinya selama ini mengalami kesulitan untuk tidur dikarenakan masalah, konflik serta kecemasan yang dialaminya selama ini. Sehingga subyek mulai merasa bisa tidur di malam hari. Akan tetapi, keinginan dan motivasi dari dalam diri subjek tidak didukung oleh keluarga maupun lingkungan sosial yang masih kurang. Sehingga, keberhasilan dari terapi yang dilakukan cukup.

Meskipun relaksasi sebagai teknik yang kurang diminati, namun pada kenyataanna sangat membantu subjek dalam mengurangi keluhan imsomnia yangdirasakan. Restrukturisasi kognitif memberikan peluang bagi subjek dalam membantu berpikir positif supaya tidak muncul kecemasannya dan berani menghadapi situasi sosial yang sesungguhnya.

\section{DAFTAR RUJUKAN}

Alwisol. 2004. Psikologi Kepribadian, Edisi Revisi. Malang : UMM Press

Bixler EO, Kales A, Soldatos CR, Kales JD, Healey S. Prevalaence of Sleep Disorder in The Los Angels Metropolitan Area. Am J Psychiatry. (1979).136:1257-62.

Blais FC, Gendrom L, Mimeault V, Morin CM. Evaluation del'insomnie: validation de trois quetionnaires. Encephale. (1997). 23:447-53.

Nevid, Spencer, Beverly. 2005. Psikologi Abnormal, Edisi Kelima Jilid I. Jakarta : Erlangga

Asrori, A. (2015). TERAPI KOGNITIF PERILAKU UNTUK MENGATASI. Jurnal Ilmiah 
Psikologi Terapan, 03(01), 89107.

Esty Aryani Safithry. (2014). LATIHAN RELAKSASI UNTUK MENGURANGI GEJALA INSOMNIA. Pedagogik Jurnal Pendidikan, 9(1), 70-79.

Hardani, P. T., Susanti, Y., \& Putri, E. (2016). RELAKSASI OTOT PROGRESIF DALAM MENGATASI INSOMNIA. Jurnal Keperawatan Jiwa, 4(1), 40-44.

Purwanto, S. (2008). Mengatasi insomnia dengan terapi relaksasi. Jurnal Kesehatan, 1(02), 141-147.

Soewondo, S. 2012. Stres,manajemen stres, dan relaksasi progresif. Depok: LPSP3 UI. 